\title{
ANALISA DAYA SAING DAN PELUANG EKSPORT WORTEL DI KELOMPOK TANI KATATA, PANGALENGAN, BANDUNG, JAWA BARAT
}

\author{
Muhammad Arief Budiman, Lucyana Trimo, Eti Suminartika, dan Sri Fatimah \\ Departemen Sosial Ekonomi Pertanian Fakultas Faperta Universitas Padjadjaran \\ Email: muhammad@unpad.ac.id
}

\begin{abstract}
ABSTRAK
Komoditas wortel telah lama menjadi andalan produksi salahsatu kelompok tani Katata yang berada di Pangalengan, Jawa Barat. Produksinya memiliki kualitas dan kuantitas yang tidak hanya baik dalam pemenuhan lokal saja, namun juga terhadap pemenuhan Ekspor. Tujuan dari penelitian ini adalah untuk mendapatkan pengatahuan daya saing dan peluang ekspor dari dampak kebijakan pemerintah pada usahatani wortel di Kelompok Tani Katata. Penelitian dilakukan di Kelompok Tani Katata, Pangalengan, Kabupaten Bandung. Data dianalisis dengan Policy Analysis Matrix (PAM), untuk menghitung keunggulan komparatif, keunggulan kompetitif dan dampak kebijakan pemerintah dengan menggunakan harga aktual dan harga bayangan. Hasil penelitian menunjukkan bahwa pengusahaan wortel di Kelompok Tani Katata memiliki keunggulan kompetitif karena nilai PCR sebesar 0,062 atau PCR kurang dari satu (PCR < 1). Hal yang sama menunjukkan bahwa wortel memiliki keunggulan komparatif dengan nilai DRC 0,060 atau DRC kurang dari satu (DRC < 1). Kebijakan pemerintah dinilai menghambat ekspor output dan adanya proteksi terhadap input lokal dibuktikan dengan nilai NPCO dan NPCI yang kurang dari satu. Secara keseluruhan kebijakan pemerintah yang berlaku saat ini masih belum mendukung dalam hal pengembangan dan peningkatan keunggulan komparatif dan keunggulan kompetitif pengusahaan komoditas wortel di Kelompok Tani Katata.
\end{abstract}

Kata kunci: daya saing, wortel, ekspor, Policy Analysis Matrix (PAM)

\begin{abstract}
Carrot commodity has been each mainstay production belong to Katata's farmer group in Pangalengan, West Java since long time ago. Their production have good quality and quantity which have potential for locally and export. The main of this research is to know the competitiveness and impact of government policy of the commodities carrots (case study Katata, subdistrict Pangalengan, county level Bandung).Policy Analysis Matrix (PAM) is the method to analyze data of this research to measure the comparative advantage, competitive advantage, and impact of government policy using actual price and estimation price.The result indicate that carrost in Katata have a competitive advantage because PCR value of 0.062 or PCR of less than one (PCR <1).Its also indicate that carrot has a comparative advantage with the value of the DRC 0.060 or DRC less than a $(D R C<1)$.The government policy is rated to inhibit the outpur export and protection againts locale input by the value of an NPCO and NPCI is less than one.Overall the policy is still not supporting development and improvement comparative advantage and competitive advantage for carrot business in Katata.
\end{abstract}

Keywords: competitiveness, carrots, export, Policy Analysis Matrix (PAM) 


\section{PENDAHULUAN}

Kecamatan Pangalengan, Kabupaten Bandung, Jawa Barat dimana merupakan salah satu sentra produksi terutama berupa sayuran bermutu tinggi. Sayuran yang dibudidayakan di Pangalengan diantaranya adalah cabe, wortel, brokoli, tomat, sawi dan selada ${ }^{1}$. Menurut data statistik luas panen dari wortel di Kecamatan Pangalengan adalah 1.120,94Ha dengan kisaran produksi 3.167 ton dan wortel merupakan beberapa dari salah satu produk unggulan yang ada di Kecamatan Pangalengan (BPS Kabupaten Bandung, 2015). Salah satu kelompok tani yang membudidayakan hortikultura di Pangalengan adalah Kelompok Tani Katata yang berada di Desa Margamekar ini memiliki 125 anggota yang tersebar di 8 desa.

Tabel 1.

Volume Ekspor Impor Wortel Tahun 2012-2014

\begin{tabular}{llll}
\hline \multirow{2}{*}{ Tahun } & \multicolumn{2}{l}{ Volume $(\mathrm{kg})$} & $\begin{array}{l}\text { Selisih Ekspor } \\
\text { Impor Wortel }\end{array}$ \\
\cline { 2 - 4 } & Ekspor & Impor & Impor \\
\hline 2012 & 72750 & 63231841 & -63159091 \\
2013 & 22890 & 18598765 & -18575875 \\
2014 & 38310 & 41526990 & -41488680 \\
\hline
\end{tabular}

Sumber: Kementerian Pertanian (2015)

Dengan kondisi seperti itu, maka perlu diketahui: (1) Keadaan kelompok tani wortel dan daya saing wortel Kelompok Tani Katata, (2) Dampak kebijakan Pemerintah dilihat dari faktor inpu, output dan input-outputnya.

\section{METODE PENELITIAN}

Metode penelitian yang digunakan berupa studi kasus. Tempat yang dijadikan objek penelitian yaitu Kelompok Tani Katata yang dikaitkan dengan daya saing dan dampak kebijakan Pemerintah terhadap komoditas wortel.Data yang digunakan adalah data primer dan data sekunder. Data primer diperoleh dengan melakukan wawancara dengan ketua dan anggota Kelompok Tani Katata, sedangkan data sekunder diperoleh dari dinas terkait dan studi

kepustakaan.Teknik pengambilan responden dilakukan secara purposive terhadap 10 orang petani anggota Kelompok Tani Katata. Data yang diperoleh dari lapangan diolah dan

\footnotetext{
${ }^{1}$ Press Release Humas Setda Kabupaten Bandung, "Pangalengan, Sentra Produksi Sayuran Bernilai Tinggi", diakses dari Pemerintah Kabupaten Bandung [Online]
}

dimasukkan ke dalam Policy Analysis Matrix (PAM)table.

Tabel 2.

Matrik Analisis Kebijakan (PAM)

\begin{tabular}{|c|c|c|c|c|}
\hline \multirow{2}{*}{ Uraian } & \multirow{2}{*}{$\begin{array}{l}\text { Penerimaan } \\
\text { Output }\end{array}$} & \multicolumn{2}{|c|}{ Biaya Input } & \multirow{2}{*}{$\begin{array}{l}\text { - Keun- } \\
\text { tungan }\end{array}$} \\
\hline & & Tradable & $\begin{array}{l}\text { Non } \\
\text { Tradable }\end{array}$ & \\
\hline $\begin{array}{l}\text { Harga } \\
\text { Privat }\end{array}$ & A & B & $\mathrm{C}$ & $\mathrm{D}$ \\
\hline $\begin{array}{l}\text { Harga } \\
\text { Sosial }\end{array}$ & E & $\mathrm{F}$ & $\mathrm{G}$ & $\mathrm{H}$ \\
\hline $\begin{array}{l}\text { Diver- } \\
\text { gensi }\end{array}$ & $\mathrm{I}=\mathrm{A}-\mathrm{E}$ & $\mathrm{J}=\mathrm{B}-\mathrm{F}$ & $\mathrm{K}=\mathrm{C}-\mathrm{G}$ & $\mathrm{L}=\mathrm{D}-\mathrm{H}$ \\
\hline
\end{tabular}

Sumber :Pearson et al. (2005)

Keterangan :

Private Profitability $(\mathrm{D})=(\mathrm{A})-(\mathrm{B}+\mathrm{C})$

Social Profitability $(\mathrm{H})=(\mathrm{E})-(\mathrm{F}+\mathrm{G})$

Social Profitability $(\mathrm{H})=(\mathrm{E})-(\mathrm{F}+\mathrm{G})$

Output Transfer $(\mathrm{I})=(\mathrm{A})-(\mathrm{E})$

Input Transfer $(\mathrm{J})=(\mathrm{B})-(\mathrm{F})$

FactorTransfer $(\mathrm{K})=(\mathrm{C})-(\mathrm{G})$

Net Transfer $(\mathrm{L})=(\mathrm{D})-(\mathrm{H})=\mathrm{I}-(\mathrm{J}+\mathrm{K})$

Private Cost Ratio $(\mathrm{PCR})=\mathrm{C} /(\mathrm{A}-\mathrm{B})$

Dom Resou Cost Ratio $($ DRCR $)=\mathrm{G} /(\mathrm{E}-\mathrm{F})$

Nom Protect Coef Output $(\mathrm{NPCO})=\mathrm{A} / \mathrm{E}$

Nom Protect Coef Input $(\mathrm{NPCI})=\mathrm{B} / \mathrm{F}$

Effective Protect Coef $(\mathrm{EPC})=(\mathrm{A}-\mathrm{B}) /(\mathrm{E}-\mathrm{F})$

Profitability Coefficient $(\mathrm{PC})=\mathrm{D} / \mathrm{H}$

Subsidy Ratio to Producers $(\mathrm{SRP})=\mathrm{L} / \mathrm{E}$

\section{HASIL DAN PEMBAHASAN}

Daya saing wortel di Kelompok Tani

Katata akan tergambar melalui hasil perhitungan dari PAM, yaitu seperti tabel dibawah ini.

Tabel 3.

Hasil Perhitungan Policy Analysis Matrix

\begin{tabular}{lllll}
\hline \multirow{2}{*}{ Komponen Pendapatan } & \multicolumn{2}{l}{ Input } & \\
\cline { 2 - 4 } & Tradable & $\begin{array}{l}\text { Non- } \\
\text { Tradable }\end{array}$ & \\
\hline Privat & 126312500 & 6806960 & 7420466 & 112085074 \\
Sosial 131656276 & 8242505 & 7420466 & 115993305 \\
Divergensi (5343776) & $(143545)$ & 0 & $(3908231)$ \\
\hline
\end{tabular}

Private Profitability (PP) untuk pengusahaan komoditas wortel di Kelompok Tani Katata adalah Rp 112.085.073,00hal ini menandakan bahwa penerimaan yang diperoleh petani lebih besar dibanding dengan biaya yang dikeluarkannya. Terlihat jelas bahwa kegiatan usahatani ini menguntungkan secara finansial sehingga layak untuk diusahakan. Private Cost Ratio (PCR) dari pengusahaan komoditas wortel adalah 0,062. Nilai PCR 0,062 dapat diartikan bahwa untuk mendapatkan nilai tambahan output sebesar 
satu satuan diperlukan biaya tambahan factor domestik adalah 0,062 .

Secara keseluruhan usahatani wortel di Kelompok Tani Katata menguntungkan dari sisi finansial maupun ekonomi sehingga sangat direkomendasikan untuk diusahakan. Selain itu juga memiliki keunggulan kompetitif dan keunggulan komparatif yang dilihat dari nilai PCR $<1$ dan DRC $<1$.

\section{Dampak Kebijakan Pemerintah} Terhadap Wortel Di Kelompok Tani Katata. Hasil dari perhitungan Policy Analysis Matrix (PAM) pada Tabel 4, dapat diketahui dampak kebijakan pemerintah terkait usahatani wortel di Kelompok Tani Katata sebagai berikut:

Tabel 3.

Indikator Dampak Kebijakan Pemerintah Pada Usahatani Wortel di Kelompok Tani Katata.

\begin{tabular}{lll}
\hline Jenis Kebijakan & Indikator & Nilai \\
\hline Kebijakan pada & OT & $-5.343 .776,6$ \\
Output & NPCO & 0,96 \\
Kebijakan pada & IT & $-1.435 .545,185$ \\
Input & NPCI & 0,83 \\
& FT & 0 \\
Kebijakan Input- & EPC & 0,97 \\
Output & PC & $-3.908 .231,5$ \\
& SRP & 0,97 \\
& & $-0,03$ \\
\hline
\end{tabular}

Secara keseluruhan, analisis dampak kebijakan terhadap output wortel di Kelompok Tani Katata mengindikasikan bahwa adanya intervensi pemerintah yang menyebabkan perbedaan keuntungan petani dibandingkan dengan tidak adanya intervensi kebijakan pemerintah. Kebijakan pemerintah membuat keuntungan petani lebih rendah dibandingkan keuntungan yang diterima seharusnya. Dengan kata lain, kebijakan pemerintah terhadap output tidak mendukung peningkatan keunggulan kompetitif komoditas wortel di lokasi penelitian.

Input transfer untuk pengusahaan wortel di Kelompok Tani Katata adalah Rp 1.435.545,185 yang bernilai negatif. Hal ini disebabkan oleh biaya inputtradable dalam harga privat lebih rendah dibandingkan dengan biaya inputtradable dalam harga sosialnya. Hal tersebut mengindikasikan adanya implisit subsidi atau transfer sumberdaya ke dalam sistem. Nilai NPCI dari pengusahaan wortel di Kelompok Tani Katata adalah 0,83 . Hal ini berarti terdapat kebijakan subsidi atas inputtradable yang menyebabkan harga domestik lebih rendah dibandingkan dengan harga dunia dan seolah-olah disubsidi oleh kebijakan yang ada. Nilai factor transfer untuk pengusahaan wortel adalah 0 . Hal ini berarti tidak adanya distorsi kebijakan pemerintah pada faktor domestik. Hal ini dikarenakan faktor domestik seperti tenaga kerja, modal dan lahan dianggap sama nilainya baik pada harga sosial maupun harga privat.

Nilai untukEffective Protection

Coefficient (EPC) pengusahaan wortel adalah 0,97 yang artinya tidak adanya perlindungan atau proteksi pemerintah terhadap usahatani wortel di Kelompok Tani Katata. Hal ini terlihat dari harga wortel domestik lebih rendah dibandingkan dengan harga wortel dunia.Nilai yang didapat untuk net transfer adalah Rp 3.908.231,415per hektar yang bernilai negatif. Hal ini mengindikasi bahwa produsen kehilangan keuntungan dengan adanya kebijakan pemerintah yang diterapkan pada input dan output.

Nilai Profitability Coefficient (PC) untuk pengusahaan wortel meunjukkan tidak adanya proteksi atau perlindungan dari pemerintah terhadap pelaku usahatani wortel di Katata yaitu 0,97. Nilai ini menunjukkan bahwa kebijakan pemerintah telah membuat kehilangan keuntungan yang diperoleh petani lebih tinggi dibandingkan tanpa adanya kebijakan.Nilai PC dapat menjadi indikator yang menunjukkan dampak insentif dari semua kebijakan output, kebijakan input asing dan input domestik (transfer net policy).

Nilai Subsidy Ratio Producers (SRP) menunjukkan bahwa nilai yang diperoleh untuk pengusahaan wortel di lokasi penelitian senilai - 0,03 . Hal ini menunjukkan bahwa kebijakan yang dibuat pemerintah yang berlaku hingga kini menyebabkan produsen mengeluarkan biaya produksi lebih besar dari biaya imbangan untuk berproduksi. Secara keseluruhan dan umumnya, kebijakan pemerintah yang berlaku saat ini belum menguntungkan bagi pengembangan dan peningkatan daya saing wortel.

\section{PENUTUP}

1. Bagi pengusahaan wortel di Kelompok Tani Katata memiliki keunggulan komparatif dan keunggulan kompetitif yang hampir sama. Untuk keunggulan komparatifnya dilihat dari nilai Domestic Resources Cost (DRC) sebesar 0,060 
sedangkan untuk keunggulan

kompetitifnya dilihat dari nilai Privat Cost

Ratio (PCR) sebesar 0,062. Sehingga

diindikasi bahwa wortel ini memiliki daya

saing dan peluang ekspor serta mampu

bersaing dengan komoditi sejenis baik impor yang terdapat dalam negeri maupun mancanegara.

2. Kebijakan pemerintah baik pada kebijakan output, input maupun input-output belum mampu mendukung pengusahaan wortel dalam pengembangan dan peningkatan keunggulan komparatif dan keunggulan kompetitif wortel di Kelompok Tani Katata. Hal ini dapat dilihat dari nilai NPCO yang didapat sebesar 0,96yang berarti ada kebijakan pemerintah yang menghambat ekspor ouput berupa pajak. Sedangkan untuk nilai NPCI yang didapat sebesar 0,83 yang berarti adanya proteksi terhadap input lokal dan mengindikasikan adanya subsidi terhadap inputtradabel sehingga petani mengeluarkan biaya yang lebih rendah dibandingkan biaya input tradabel sosialnya.

\section{DAFTAR PUSTAKA}

Badan Pusat Statistik. 2015. Statistik Kecamatan Pangalengan. Statistik Kabupaten Bandung

Cahyono, Bambang. 2002. Wortel; Teknik Budidaya dan Analisis Usaha Tani. Yogyakarta : Kanisius
Direktorat Jenderal Hortikultura. 2013. Nilai PDB Hortikultura di Indonesia Tahun 2010-2012. Dirjen Hortikultura : Jakarta

Direktorat Jenderal Hortikultura dan Pusdatin (2015). Nilai PDB Hortikultura di Indonesia Tahun 2010-2014. Dirjen Hortikultura : Jakarta

Kementerian Pertanian. 2015. Ekspor Komoditi Pertanian Berdasarkan Negara Tujuan. [Online] http://aplikasi.pertanian.go.id/eksim201 2/hasileksporNegara.asp.

Kuraisin, Vivin. 2006. Analisis Daya Saing dan Dampak Perubahan Kebijakan Pemerintah Terhadap Komoditi Susu Sapi. Bogor : Institut Pertanian Bogor

Maftuhah, Gina Nur. 2011. Wortel Impor Kurang di Sukai Masyarakat. [Online], (http://economy.okezone.com/read/2011 /12/26/320/547327/wortel-imporkurang-disukai-masyarakat

Mulyahati, A. 2005. Saluran Pemasaran Wortel di Kawasan Agropolitan Cianjur. [Skripsi]. IPB Bogor

Pearson, S., C. Gotsch and S. Bahri.2005. Aplikasi Policy Analysis Matrix Pada Pertanian Indonesia.Terj. Sjaiful Bahari (ed). Jakarta: Buku Obor.

Pusat Data dan Informasi. 2015. Nilai PDB Hortikultura di Indonesia Tahun 20132014. Pusdatin Kementan : Jakarta

Rukmana, R. 1995. Bertanam Wortel. Yogyakarta : Kanisius. 